\title{
Determination of pesticides in the source and drinking waters in Londrina, Paraná, Brazil
}

\section{Determinação de agrotóxicos em água de manancial e água de abastecimento público em Londrina, Paraná, Brasil}

\author{
Laura Fernanda Condota Borba de Souza ${ }^{1 *}$; Cassiana Caroline Montagner ${ }^{2}$; \\ Mariana Bortholazzi Almeida ${ }^{3}$; Emília Kiyomi Kuroda ${ }^{4}$; Cristiane Vidal2; \\ Roberta Lemos Freire ${ }^{5}$
}

\begin{abstract}
The Brazilian agricultural model is based on the intensive use of pesticides. Once in the environment, these compounds might target hydric sources, mainly through soil lixiviation or during crop application, exposing water biota as well as humans to contaminants. The objective of this research was identify the presence of 14 pesticides (ametrine, atrazine, azoxystrobin, carbendazim, carbofuran, clomazone, chlorpirifos, diuron, hexazinone, imidacloprid, malathion, simazine, tebuconazole and tebuthiuron) in source water samples and drinking water samples from the city of Londrina, Paraná State, Brazil. 24 water samples were collected biweekly from December 2014 to October 2015. The sample preparation was done using Solid Phase Extraction (SPE) with $3 \mathrm{~mL} / 500 \mathrm{mg}$ C-18 cartridges. Pesticide determination was performed applying Liquid Chromatography tandem Mass Spectrometry (LC-MS/MS). The frequencies of detection of some compounds in source water were: atrazine (85\%), azoxystrobin $(95 \%)$, carbendazim $(83 \%)$, diuron $(75 \%)$, imidacloprid $(95 \%)$, simazine $(12 \%)$, hexazinone $(4 \%)$, tebutiuron (4\%) and tebuconazole (33\%). In the water supply, the following were detected: atrazine (79\%), azoxystrobin (95\%), carbendazim (8\%), diuron (83\%), imidacloprid (95\%), simazine $(12 \%)$, hexazinone (4\%), tebuthiuron (8\%) and tebuconazole (33\%). Some of these compounds are included in Brazilian legislation, and in these cases, the concentrations determined in this study varied between 241 and $7 \mathrm{ng} \mathrm{L}^{-1}$, which were lower than the maximum allowable concentrations for each of the compounds. Key words: Pesticides. Drinking water. LC-MS/MS. Surface water.
\end{abstract}

\section{Resumo}

O modelo de agricultura brasileiro é baseado no uso intensivo de agrotóxicos. Uma vez no ambiente, estes compostos podem atingir recursos hídricos, principalmente através da lixiviação ou durante a aplicação, expondo a biota aquática e até mesmo humanos, aos contaminantes. O objetivo deste trabalho foi identificar a presença dos agrotóxicos ametrina, atrazina, azoxistrobina, carbendazim, carbofurano, clomazona, clorpirifós, diuron, hexazinona, imidacloprido, malation, simazina, tebuconazol e tebutiuron em amostras de água de manancial e de abastecimento público da cidade de Londrina, Paraná, Brasil.

1 Discente, Departamento de Ciências Fisiológicas, Universidade Estadual de Londrina, UEL, Londrina, PR, Brasil. E-mail: lauf. vet@gmail.com

2 Prof ${ }^{a}$, Instituto de Química, Universidade Estadual de Campinas, UNICAMP, Campinas, SP, Brasil. E-mail:montagner@iqm. unicamp.br

3 Discente, Departamento de Química, UEL, Londrina, PR, Brasil. E-mail:maribortholazzi@hotmail.com

4 Prof ${ }^{a}$, Departamento de Construção Civil, UEL, PR, Brasil. E-mail: ekkuroda@uel.br

5 Prof ${ }^{\mathrm{a}}$ Dr $^{\mathrm{a}}$, Departamento de Medicina Veterinária Preventiva, CCA, UEL, PR, Brasil. E-mail:rlfreire@uel.br

Author for correspondence 
Foram coletadas 24 amostras, quinzenalmente, de Dezembro de 2014 a Outubro de 2015. Para o preparo das amostras foi utilizado Extração em Fase Sólida (SPE) com cartuchos de $3 \mathrm{~mL} \mathrm{C-18} \mathrm{de} 500 \mathrm{mg}$. A determinação de agrotóxicos foi realizada utilizando Cromatografia Líquida acoplada à Espectrometria de Massas (LC-MS/MS). Nas amostras do manancial, foram detectados os compostos atrazina (85\%), azoxistrobina (95\%), carbendazin (83\%), diuron (75\%), imidacloprido (95\%), simazina $(12 \%)$, hexazinona (4\%), tebutiuron (8\%) e tebuconazol (33\%). Nas amostras de água para abastecimento público, foram detectados atrazina (79\%), azoxistrobina (95\%), carbendazim (8\%), diuron $(83 \%)$, imidacloprido (95\%), simazina (12\%), hexazinona (4\%), tebutiuron (8\%) e tebuconazol (33\%). Alguns destes compostos estão inseridos na legislação brasileira e nestes casos, as concentrações determinadas neste estudo variaram entre 241 e $7 \mathrm{ng} \mathrm{L}^{-1}$, as quais foram inferiores às máximas concentrações determinadas para cada um dos compostos.

Palavras-chave: Pesticidas. Contaminação. LC-MS/MS. Águas superficiais.

\section{Introduction}

The intensive use of pesticides as a tool to optimize production and facilitate pest control has caused the emergence of adverse effects on flora and fauna (GAMA et al., 2013). Currently, Brazil is the largest consumer of pesticides in the world, and the risks related to the exposure to these compounds are a reality that should be considered relevant in the country (ALBUQUERQUE et al., 2016; BRASIL, 2013, 2011; FAO, 2014). The sources of groundwater and surface water are exposed to pesticides used in agricultural and non-agricultural areas, since water resources act as integrators of the biogeochemical processes of any region (SILVA et al., 2011; RIBEIRO et al., 2007). After application, pesticides suffer various physical, chemical and biological processes that determine their fate in the environment, with leaching being the most important factor related to the contamination of water bodies (SPADOTTO et al., 2004). The pesticides in the water can reach non-target organisms, affecting the endocrine systems of animals and humans through chronic exposure, even in concentrations of nanograms per liter (MONTAGNER et al., 2014; GRANELLA et al., 2013). In Brazil, there are currently a large number of authorized compounds for different crops, needing knowledge about the scenario of contamination of water bodies, especially regarding those that serve for public supply (RIBEIRO et al., 2013). Some studies demonstrate the presence of pesticides in sewage effluents at levels of concern (MONTAGNER et al., 2017). The objective of this work was to evaluate the presence of pesticides in source and drinking water samples collected at a public Drinking Water Treatment Plant (DWTP) in the city of Londrina, Paraná State, Brazil, using a selective analytical technique with high sensitivity. This approach will deepen the understanding of the scenario of contamination by pesticides in this country and thus support future decision-making in the scope of public policies related to water quality management.

\section{Materials and Methods}

\section{Sampling and local area}

This study was conducted at a DWTP in the city of Londrina, Paraná State, whose the water source is the Tibagi River, which has an average volume of treated water around $1446 \mathrm{~L}$ per second. The treatment plant performs conventional water treatment, through processes such as coagulation, flocculation, decantation, filtration and subsequent disinfection with fluoridation. Samples were collected directly from the captation and final treatment taps, within the treatment plant itself. Twenty-four samples of source and drinking water were collected in polyethylene bottles (1 L), previously washed with ultrapure water and dried at room temperature, transported and kept under refrigeration until extraction. Samples were 
extracted on the same day of collection.

The samples were collected fortnightly in the period of December 2014 to October 2015.

\section{Pesticides}

The target pesticides were selected based on a survey carried out on the main compounds in the State of Paraná, Brazil. The insecticides include carbofuran, imidacloprid, chlorpyrifos and malathion; the herbicides include ametrine, atrazine, simazine, hexazinona, clomazone, diuron and tebuthiuron; the fungicides include azoxystrobin, carbendazim and tebuconazole. Relevant physicalchemical properties of the selected pesticides are presented in Table 1.

Table 1. Physio-chemical properties of the selected pesticides.

\begin{tabular}{cccccc}
\hline Pesticides & $\begin{array}{c}\text { Chemical } \\
\text { group }\end{array}$ & Molecular formula & $\begin{array}{c}\text { Log } \\
\text { Kow }\end{array}$ & CAS number & $\begin{array}{c}\text { Water solubility } \\
\text { (mg L }\end{array}$ \\
\hline Ametrine & Herbicide & $\mathrm{C}_{9} \mathrm{H}_{17} \mathrm{~N}_{5} \mathrm{~S}$ & 2.98 & $834-12-8$ & 200 \\
Atrazine & Herbicide & $\mathrm{C}_{8} \mathrm{H}_{14} \mathrm{CIN}_{5}$ & 2.70 & $1912-24-9$ & 33 \\
Azoxystrobin & Fungicide & $\mathrm{C}_{22} \mathrm{H}_{17} \mathrm{~N}_{3} \mathrm{O}_{5}$ & 2.50 & $131860-33-8$ & 6 \\
Carbendazim & Fungicide & $\mathrm{C}_{9} \mathrm{H}_{9} \mathrm{~N}_{3} \mathrm{O}_{2}$ & 1.48 & $10605-21-7$ & 8 \\
Carbofurane & Insecticide & $\mathrm{C}_{12} \mathrm{H}_{15} \mathrm{NO}_{3}$ & 2.32 & $1563-66-2$ & 351 \\
Clomazone & Herbicide & $\mathrm{C}_{12} \mathrm{H}_{14} \mathrm{ClNO}_{2}$ & 2.50 & $81777-89-1$ & 1100 \\
Chlorpirifos & Insecticide & $\mathrm{C}_{9} \mathrm{H}_{11} \mathrm{Cl}_{3} \mathrm{NO}_{3} \mathrm{PS}$ & 1.82 & $2921-88-2$ & 1 \\
Diuron & Herbicide & $\mathrm{C}_{9} \mathrm{H}_{10} \mathrm{Cl}_{2} \mathrm{~N}_{2} \mathrm{O}$ & 2.68 & $330-54-1$ & 42 \\
Hexazinone & Herbicide & $\mathrm{C}_{12} \mathrm{H}_{20} \mathrm{~N}_{4} \mathrm{O}_{2}$ & 1.85 & $51235-04-2$ & 33 \\
Imidacloprid & Insecticide & $\mathrm{C}_{9} \mathrm{H}_{10} \mathrm{CIN}_{5} \mathrm{O}_{2}$ & 0.57 & $138261-41-3$ & 610 \\
Malathion & Insecticide & $\mathrm{C}_{10} \mathrm{H}_{19} \mathrm{O}_{6} \mathrm{PS}_{2}$ & 2.36 & $121-75-5$ & 145 \\
Simazine & Herbicide & $\mathrm{C}_{7} \mathrm{H}_{12} \mathrm{ClN}_{5}$ & 2.18 & $122-34-9$ & 5 \\
Tebuconazole & Fungicide & $\mathrm{C}_{16} \mathrm{H}_{22} \mathrm{ClN}_{30}$ & 3.70 & $107534-96-3$ & 36 \\
Tebuthiuron & Herbicide & $\mathrm{C}_{9} \mathrm{H}_{16} \mathrm{~N}_{4} \mathrm{OS}$ & 1.79 & $34014-18-1$ & 2500 \\
\hline
\end{tabular}

Adapted from Montagner et al. (2014).

\section{Reagents and chemicals}

High purity standards of pesticides, including ametrine $(98.5 \%)$, atrazine $(98.8 \%)$, azoxystrobin (99.7\%), carbendazim (97\%), carbofuran (99.9\%), clomazone (99.7\%), chlorpyrifos $(99.7 \%)$, diuron (99.6\%), hexazinone $(99.9 \%)$, imidacloprid (99.9\%), malation (97.5\%), simazine (99.9\%), tebuconazole (99.7\%) and tebuthiuron (99.9\%), were purchased from Sigma-Aldrich ${ }^{\circledR}$ (Munich, Germany). Individual stock solutions (400 mg L-1) of each pesticide were prepared from the appropriate solid standards in methanol (J.T. Baker, Philipsburg, NJ, EUA) and stored in amber glass bottles $\left(-4^{\circ} \mathrm{C}\right)$.
Calibration solutions were prepared at different concentrations $\left(500,100,50,10,5\right.$ e $\left.1 \mu \mathrm{g} \mathrm{L}^{-1}\right)$ in the $70 / 30(\mathrm{v} / \mathrm{v}) \mathrm{H}_{2} \mathrm{O}-\mathrm{MeOH}$ solution.

\section{Solid-phase extraction (SPE)}

A 250-mL sample was vaccum filtered using a nylon membrane $(0.22 \mu \mathrm{m}$, Millipore, USA). The solid phase extraction (SPE) was performed using Strata ${ }^{\circledR}$ C18 Sep-pak (500 mg, Phenomenex, USA) in the manifold system under vaccum. Each cartridge was conditioned with $3 \mathrm{~mL}$ methanol and $3 \mathrm{~mL}$ ultrapure water, avoinding dry the sorbent. 
The sample was percolated at approximately 2 $\mathrm{mL} \mathrm{min}^{-1}$. A clean up was performed with $2 \mathrm{~mL}$ of purified water and then the cartridge was dried for 20 minutes and stored in a freezer at $-4^{\circ} \mathrm{C}$ until the LC-MS/MS analysis.

The elution of analytes was done with $3 \mathrm{~mL}$ of methanol and $3 \mathrm{~mL}$ acetonitrile. Solvents were evaporated to dryness with a flow of ultrapure nitrogen gas, and the compounds were redissolved adding $1 \mathrm{~mL}$ of the 70/30 (v/v) $\mathrm{H}_{2} \mathrm{O}-\mathrm{MeOH}$ solution. Final extracts were filtered with a nylon membrane (13 $\mathrm{mm}, 0.20 \mu \mathrm{m}$ pore size) and transferred to vials.

\section{LC-MS/MS Determination}

The LC-MS/MS analyses were realized using an Agilent 1200 Series LC system coupled to an Agilent 6410 triple quadrupole mass spectrometer with an electrospray ionization source (ESI) and software MassHunter (Agilent, Palo Alto, CA, USA), to evaluate the chromatographic and mass data. The chromatographic separation was realized at $30^{\circ} \mathrm{C}$, using a reversed-phase Zorbax SB-C18 (2.1 x 30 $\mathrm{mm}$, particle size $3.5 \mu \mathrm{m}$, Agilent, Santa Clara, CA,
USA) and gradient elution using water and methanol and $0.01 \%$ formic acid. Mobile-phase solvents were filtered through $0.2-\mu \mathrm{m}$ nylon membranes $\left(\right.$ Sigma-Aldrich $^{\circledR}$, Munich, Germany). Gradient elution was done at a flow rate of $0.3 \mathrm{~mL} \mathrm{~min}{ }^{-1}$ and increasing the organic solvent concentrations from $30 \%$ to $60 \%$ in 1.2 min for 3 minutes, followed by an increase to $70 \%$ in $3.5 \mathrm{~min}$, and kept constant for 4 minutes. After being reset to the initial conditions, the system was re-equilibrated for 5 minutes. The injection volume was $10 \mu \mathrm{L}$.

After the chromatographic separation, the compounds were ionized using ESI operating in the positive mode for all compounds. The following optimized parameters were used: drying gas temperature of $350^{\circ} \mathrm{C}$, drying gas flow rate of $10 \mathrm{~L} \mathrm{~min}^{-1}$, nebulizing gas pressure of $20 \mathrm{psi}$ and capillary voltage of $4000 \mathrm{~V}$, using nitrogen as the collision gas. The mode of acquisition was multiple reaction monitoring (MRM) transitions between the precursor product ions, which was used for confirmation and quantification of the studied compounds (Table 2).

Table 2. LC-MS/MS quantification parameters used for each pesticide.

\begin{tabular}{cccccc}
\hline Pesticides & Retention time (min) & Precursor ion $(\boldsymbol{m} / z)$ & Product ion $(\boldsymbol{m} / z)$ & Collision energy $(\mathbf{e V})$ & Polarity \\
\cline { 3 - 5 } Ametrine & 5,8 & 228,2 & 186,1 & 15 & Positive \\
Atrazine & 5,7 & 216,2 & 174,1 & 15 & Positive \\
Azoxystrobin & 7 & 404,2 & 344,1 & 5 & Positive \\
Carbendazim & 0,8 & 192,1 & 160,1 & 20 & Positive \\
Carbofurane & 4,7 & 222 & 123 & 10 & Positive \\
Clomazone & 6,4 & 240,1 & 125 & 1 & Positive \\
Chlorpirifos & 7,5 & 350 & 198 & 20 & Positive \\
Diuron & 6 & 233 & 72,1 & 20 & Positive \\
Hexazinone & 4,7 & 253,2 & 171,1 & 8 & Positive \\
Imidacloprid & 1,1 & 256 & 175,1 & 15 & Positive \\
Malathion & 7,3 & 331 & 99 & 15 & Positive \\
Simazine & 4,3 & 202 & 124 & 15 & Positive \\
Tebuconazole & 9,2 & 308,2 & 70 & 10 & Positive \\
Tebuthiuron & 5 & 229,1 & 172,1 & 10 & Positive \\
\hline
\end{tabular}




\section{Results and Discussion}

The efficiency of SPE extraction was measured by recovery tests using synthetic samples of 200 and $500 \mathrm{ng} \mathrm{L^{-1 }}$ of each target pesticide. Figure 1 shows that the recoveries varied between 60 and 115\%, which were considered appropriate for the required chemical analyses.

Figure 1. Average extraction efficiency for each compound at two levels of fortification $\left(500 \mathrm{ng} \mathrm{L}^{-1}\right.$ and $\left.200 \mathrm{ng} \mathrm{L} \mathrm{L}^{-1}\right)$.

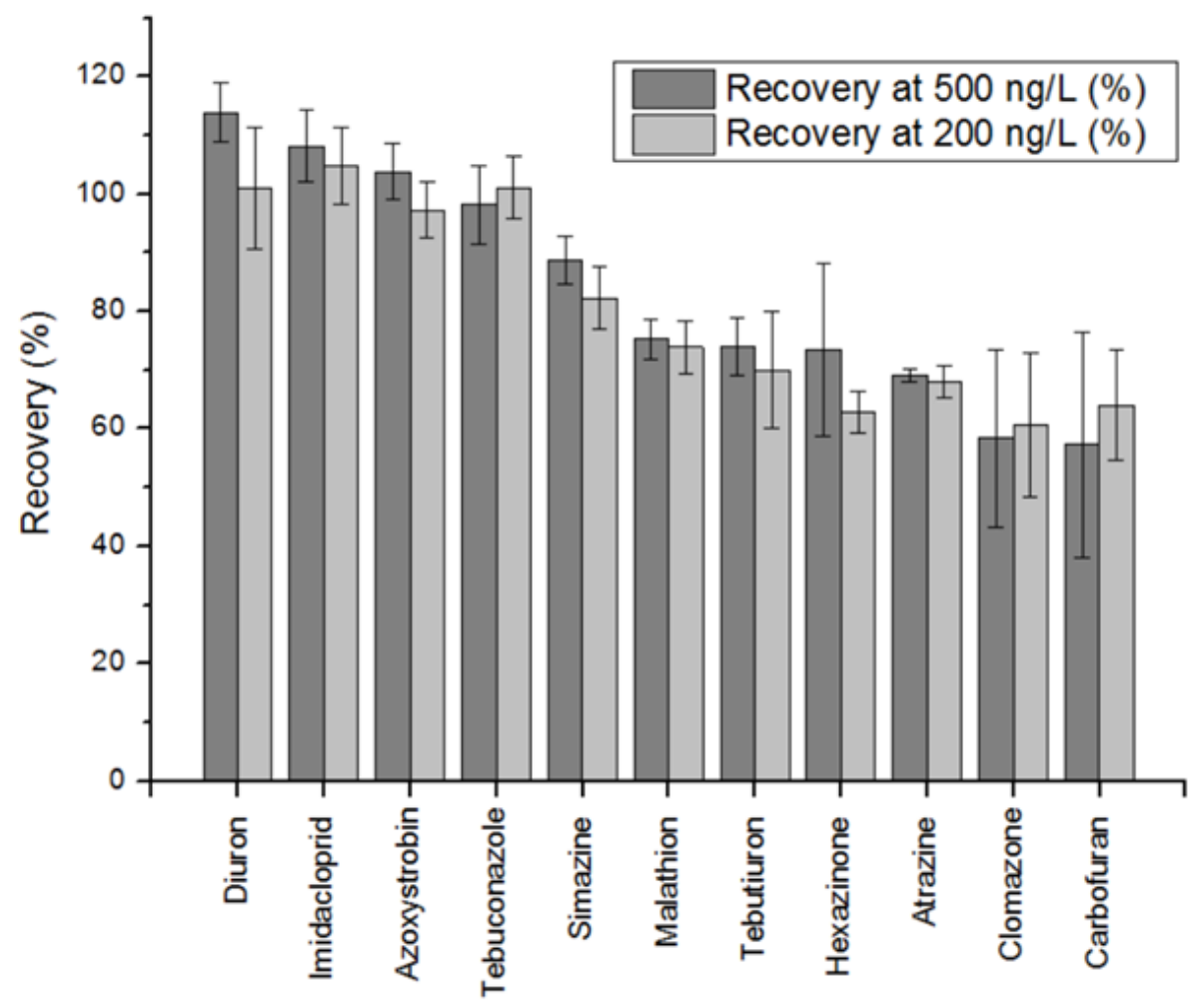

The limit of detection (LOD) and the limit of quantification (LOQ) of the analytical method were

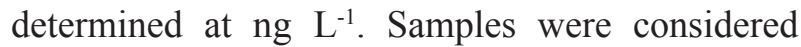
positive when detected at concentrations above the LOD, and concentrations were determined only when they exceeded the LOQ of the analytical method. Samples were considered negative (ND) when determined at concentrations below the detection limit of the method. The pesticides detected in the samples at concentrations higher than LOD and lower than LOQ were therefore considered positive but were not quantified and were expressed as values lower than the limit of quantification of the method $(<\mathrm{LOQ})$. During the study period, five of the 14 target pesticides were quantified in the freshwater and drinking water samples (carbendazim, imidacloprid, atrazine, diuron and azoxystrobin), and another four were detected at concentrations below the limit of quantification of the analytical method (simazine, hexazinone, tebuthiuron and tebuconazole). The compounds carbofuran, amethrin, clomazone, malathion and chlorpyrifos were not detected in any samples at concentrations above the LOD of the analytical method (Table 3).

Most of the target compounds, do not have values stipulated by CONAMA Resolution 357/2005 (BRASIL, 2005) and Brazil's Ministry of Health Ordinance 2914/2011 (BRASIL, 2011). 
The pesticide imidacloprid was detected in $95 \%$ of the source and water supply, with average concentrations of $27 \mathrm{ng} \mathrm{L}^{-1}$ and $36 \mathrm{ng}$ $\mathrm{L}^{-1}$, respectively. Imidacloprid belongs to the neonicotinoid group and was temporarily banned in the European Union. In Brazil, its use is being re-evaluated by IBAMA due to its toxic effects on non-target organisms, especially bees (CARRILHO et al., 2013; USEPA, 2008). According to Martini et al. (2012), imidacloprid is a compound with high transport potential when dissolved in water. Bortoluzzi et al. (2006) evaluated surface water samples in a microbasin in the region of Agudo (Rio Grande do Sul State) and detected the presence of imidacloprid by HPLC/UV in concentrations between 0.38 to $2.1 \mu \mathrm{g} \mathrm{L}^{-1}$. Studies developed by Bortoluzzi et al. (2007) evaluated the presence of imidacloprid in surface water samples from the rivers Jacuí, Guaporé and Camaquã (Rio Grande do Sul State) by HPLC/DAD and detected concentrations up to $4.53 \mu \mathrm{g} \mathrm{L}^{-1}$, which suggests that imidacloprid has a high leaching capacity.

Azoxystrobin, a fungicide of the strobilurin class, was detected in $62 \%$ of surface water samples and $58 \%$ of potable water samples, with average concentrations of $28 \mathrm{ng} \mathrm{L}^{-1}$ and $23 \mathrm{ng} \mathrm{L}^{-1}$, respectively. It is currently the most extensively fungicide used in the world (RODRIGUES et al., 2015). According to a report by the USEPA (2006), azoxystrobin is considered highly environmentally hazardous and highly toxic to aquatic organisms. Although it is poorly soluble in water, it can be leached from the source, and therefore can be found in water bodies.

The herbicide atrazine was detected in $58 \%$ of surface water samples and $79 \%$ of water supply samples. Among the compounds studied, atrazine presented the highest concentrations, $265 \mathrm{ng} \mathrm{\textrm {L } ^ { - 1 }}$ in surface water and $241 \mathrm{ng} \mathrm{L}^{-1}$ in drinking water. Atrazine is a common contaminant in water bodies, including groundwater (MOREIRA et al., 2012; BORTOLUZZI et al., 2006; COUTINHO et al., 2006; PESSOA et al., 2003). Studies on fish demonstrate the adverse effects promoted by atrazine, such as the reduction of antioxidant enzymes and biotransformation in hepatic cells of exposed fish, as well as DNA damage in different cell types (SANTOS; MARTINEZ, 2012). 


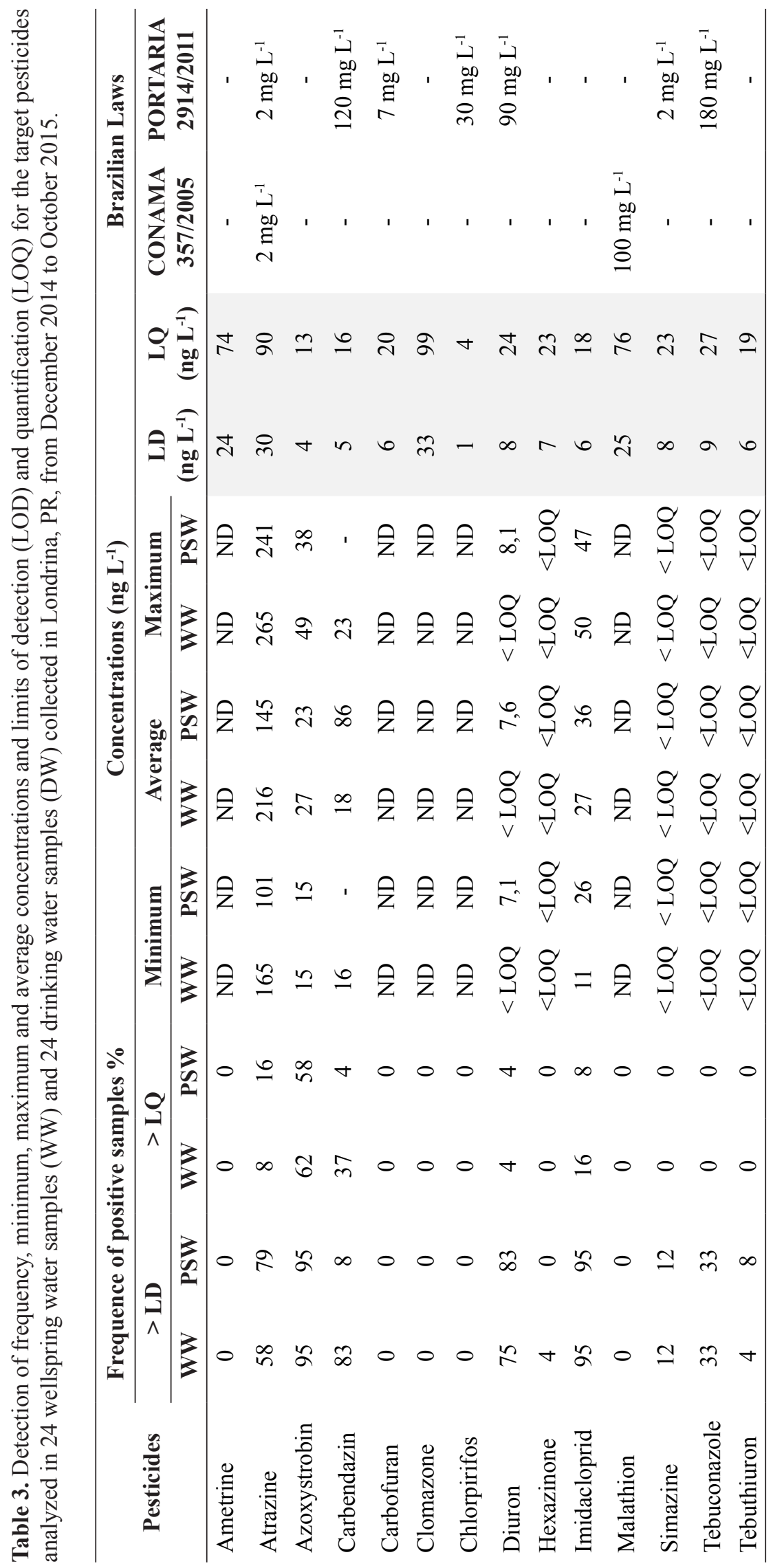


Currently, atrazine is classified as an endocrine disruptor, and studies have demonstrated that atrazine is the most frequent surface water contaminant in the USA, present in $47 \%$ of samples analyzed by GC/MS collected at High Mississippi River (USA), with average concentrations of 150 ng L-1 (TAGERT et al., 2014), wich means almost the same average obtained in this study (216 ng $\left.\mathrm{L}^{-1}\right)$.

The fungicide carbendazim was detected in $83 \%$ of surface water samples, with an average concentration of $17 \mathrm{ng} \mathrm{L}^{-1}$. However, in drinking water samples, carbendazim was detected in only $8 \%$ of the samples. According to Coutinho et al. (2006), the environmental persistence of carbendazim is variable, depending on the loss of its activity by abiotic or biotic factors, which can vary from 1 to 2 months in peat and up to 25 months in anaerobic conditions, favoring environmental contamination, mainly due to its half-life in the water of approximately 350 days. The presence of carbendazim in the environment may be related to the increase of its solubility at higher temperatures (SILVA et al., 2014). Ribeiro et al. (2013) determined the presence of carbendazim in surface water samples in a degraded source region of the São Lourenço River, using HPLC/DAD, at concentrations between 4 to $28 \mu \mathrm{g} \mathrm{L}^{-1}$. The toxic effects that carbendazim can promote in animals, such as changes in the reproduction and endocrine systems of rats and other mammals (JIANG et al., 2014). Thus, as well as in aquatic organisms, such as the induction of apoptosis, immunological toxicity and endocrine disruption (JIANG et al., 2015; CUPPEN et al., 2000).

Diuron was detected in $75 \%$ of surface water samples and $83 \%$ of drinking water samples. According to Garcia et al. (2012), diuron is a compound considered to have low mobility $(2,68)$ and low solubility in water $\left(42 \mathrm{mg} \mathrm{L}^{-1}\right)$, which may explain the low concentrations detected in this study.
Simazine was detected in $12 \%$ of both surface and drinking water samples in this study. Previous studies have demonstrated that simazine has a characteristic of medium solubility in water $(5 \mathrm{mg}$ $\mathrm{L}^{-1}$ ), as well as the potential of water contamination and show that water contamination by simazine is a concern, since this compound has a characteristic of high environmental persistence and may cause bioaccumulation (MORAES et al., 2008; DORES; DE-LAMONICA-FREIRE, 2001).

In general, the compounds were detected at low concentrations in the source water and treated water samples. However, the possibility of impact in environmental, plant and animal health cannot be ruled out, as some of these substances have been indicated as likely compounds of mutagenic action and endocrine disruption. In addition, studies demonstrate that chronic exposure to pesticides can promote deleterious effects on nontarget organisms and even on human populations (BURILLO-PUTZE et al., 2014; OLIVEIRA et al., 2014; RIGOTTO et al., 2013; COSTA; TEIXEIRA, 2012; CALDAS; SOUZA, 2000). It is also important to highlight that the samplings were punctual, and the treated water samples do not represent the spring water in these cases, once water treatment can cause desorption of the pesticides that could be adhered to the sediment. For compounds having maximum allowable concentrations prescribed in legislation, it is important to note that there are more restrictive laws than those in Brazilian legislation. In the European Union (UE), Regulation (CE) 396/2005 on February 23, 2005 established the maximum value of $0.1 \mu \mathrm{g} \mathrm{L}^{-1}$ for any pesticide in water for human consumption, and the total value allowed for the total concentration of pesticides of $0.5 \mu \mathrm{g}$ $\mathrm{L}^{-1}$. The exception occurs only for the compounds aldrin, dieldrin and heptachlor, having a maximum allowable concentration of $0.03 \mu \mathrm{g} \mathrm{L}^{-1}$ (CE, 2005). In this work, All the agrochemicals surveyed were found in lower limits than those determined by European legislation. However, the low values 
detected do not exclude the possibility that these compounds may have harmful effects on exposed ecosystems and organisms, especially in long-term exposures.

\section{Conclusion}

Considering the results obtained from the Tibagi River water samples, it is noted that there is contamination by pesticides and that the concentrations obtained were lower than the values stipulated in legislation for the predicted compounds, according to the CONAMA 357/2005 Resolution. Likewise, the concentrations determined in drinking water samples for the expected compounds are within the national water standards provided for in the Ministry of Health Ordinance 2914/2011. This study suggests the use of pesticides has had an impact on water resources of the Tibagi River. The evaluation of the compounds serves as a basis for the knowledge of the main compounds that are being used in agriculture in the region surrounding the Tibagi Basin and its tributaries and provides important parameters for future studies. This work demonstrates the presence of several pesticides in the water that are not recognized by the current legislation, so that studies are still lacking to see if these products, even at low concentrations, can cause adverse effects to exposed organisms, over time.

\section{Acknowledgments}

We thank the Sanitation Company of Paraná (SANEPAR) - Tibagi; the Laboratories for the Development of Instrumentation and Analytical Automation, Hydraulics and Sanitation of the State University of Londrina (UEL); the Laboratory of Environmental Chemistry of the Institute of Chemistry of the University of Campinas (UNICAMP) for collaboration and help throughout the research, and the National Health Foundation (FUNASA; Covenant 313/2012; Process
25100.031.386/2012-46) for financial support.

\section{Conflict of interests}

The authors declare that there is no conflict of interest.

\section{References}

ALBUQUERQUE, A. F.; RIBEIRO, J. S.; KUMMROW, F.; NOGUEIRA, A. J. A.; MONTAGNER, C. C.; UMBUZEIRO, G. A. Pesticides in Brazilian freshwaters: a critical review. Environmental Scienc: Proces \& Impacts, v. 18, n. 1, p. 779-787, 2016. DOI: 10.1039/ C6EM00268D

BORTOLUZZI, E. C.; RHEINHEIMER, D. S.; GONÇALVES, C. S.; PELLEGRINI, J. B. R.; MARONEZE, A. M.; KURZ, M. H. S.; BACAR, N. M.; ZANELLA, R. Investigation of the occurence of pesticides residues in rural wells and surface water following application to tobacco. Química Nova, São Paulo, v. 30 , n. 8 , p. $1872-1876$, 2007. DOI: $10.1590 /$ S0100-40422007000800014

BORTOLUZZI, E. C.; RHEINHEIMER, D. S.; GONÇALVEZ, C. S.; PELLEGRINI, J. B. R.; ZANELLA, R.; COPETTI, A. C. C. Contaminação de águas superficiais por agrotóxicos em função do uso do solo numa microbacia hidrográfica de Agudo, RS. Revista Brasileira de Engenharia Agrícola e Ambiental, Campina Grande, v. 10, n. 4, p. 881-887, 2006.

BRASIL. Ministério da Saúde. Monitoramento de agrotóxicos na água para consumo humano no Brasil, 2011/2012. São Paulo: Boletim Epidemiológico, v. 44, n. 17, p. 1-10, 2013.

BRASIL. Ministério da Saúde, Portaria n. 2914 de 12 de dezembro de 2011. Dispõe sobre os procedimentos para controle e de vigilância da água para consumo humano e seu padrão de potabilidade. Diário Oficial [da] União, Brasília, 2011. Anexo VII, p. 23-26.

BRASIL. Ministério da Saúde. Resolução CONAMA n. 357, de 17 de março de 2005. Dispõe sobre a classificação dos corpos de água e diretrizes ambientais para o seu enquadramento, bem como estabelece as condições e padrões de lançamento de efluentes e outras providências. Diário Oficial [da] União, Brasília, 18 mar. 2005. Seção I, p. 8-10.

BURILLO-PUTZE, G.; LUZARDO, O. P.; GARCÍA, C. P.; ZUMBADO, M.; YANES, C.; TRUJILLO-MARTÍN, M. D. M.; DEL CAMPO, C. B. F.; BOADA, L. D. 
Exposición a plaguicidas persistentes y no persistentes em población no expuesta laboralmente de la islã de Tenerife. Gaceta Sanitaria, Barcelona, v. 28, n. 4, p. 301304, 2014. DOI: 10.1016/j.gaceta.2013.11.003

CALDAS, E. D.; SOUZA, L. C. K. R. Avaliação de risco crônico da ingestão de resíduos de pesticidas na dieta brasileira. Revista de Saúde Pública, São Paulo, v. 34, n. 5, p. 529-537, out. 2000.

CARRILHO, M. P.; BOVI, T. S.; NEGRÃO, A. F.; ORSI, R. O. Influence of agrochemicals fipronil and imidacloprid on the learning behavior of Apis melifera $\mathrm{L}$. honeybees. Acta Scientiarum Animal Sciences, Maringá, v. 35 , n. 4 , p. $431-434$, oct./dec. 2013. DOI: $10.4025 /$ actascianimsci.v35i4.18683

CE. European Comission, EU Pesticides Database. Regulation (EC) N396/2005 of the European Parliament and of the council of 23 February, 2005. Disponível em: $<$ https://eur-lex.europa.eu/LexUriServ/ LexUriServ. do?uri=CONSLEG:2005R0396:20100729:EN:PDF>. Acesso em: 12 jun 2014.

COSTA, C.; TEIXEIRA, J. P. Efeitos genotóxicos dos pesticidas. Revista de Ciências Agrárias, Londrina, v. 35, n. 2, p. 19-31, jul./dez. 2012.

COUTINHO, C. F. B.; GALli, A.; MAZO, L. H.; MACHADO, S. A. S. Carbendazim e o meio ambiente: degradação e toxicidez. Pesticidas: Revista de Ecotoxicologia e Meio Ambiente, Curitiba, v. 16, n. 1, p. 63-70, jan./dez. 2006. DOI: 10.5380/pes.v16i0.7480

CUPPEN, J. G. M.; DEN BRINK, P. J. V.; CAMPS, E.; UIL, K. F.; BROCK, T. C. M. Impact of the fungicide carbendazim in freshwater microcosms. I. Water quality, breakdown of particulate organic matter and responses of macroinvertebrates. Aquatic Toxicology, Oxford, v. 48 , n. 1 , p. $233-250,2000$. DOI: 10.1016/S0166445X(99)00036-3

DORES, E. F. G.; DE-LAMONICA-FREIRE, E. M. Contaminação do ambiente aquático por pesticidas. Estudo de caso: águas usadas para consumo humano em Primavera do Leste, Mato Grosso - análise preliminar. Química Nova, São Paulo, v. 24, n. 1, p. 27-36, 2001.

FOOD AND AGRICULTURE ORGANIZATION FAO. O Estado da segurança alimentar e nutricional no Brasil: um retrato multidimensional - Relatório 2014. Brasília: Fundação Perseu Abramo, 2014. Disponível em: <https://www.fao.org.br/download/SOFI_p.pdf>. Acesso em: 12 dez. 2015.

GAMA, A. F.; OLIVEIRA, A. H. B.; CAVALCANTE, R. M. Inventário de agrotóxicos e risco de contaminação química dos recursos hídricos semiárido cearense. Química Nova, São Paulo, v. 36, n. 3, p. 462-467, 2013.
GARCIA, D. B.; ALVES, S. N. R.; CASON, J. B.; CHRISTOFFOLETI, P. J. Lixiviação de diuron, hexazinone e sulfometuron-methyl em formulação comercial e isoladamente em dois solos constrastantes. Revista Brasileira de Herbicidas, v. 11, n. 2, p. 222-230, maio/ago. 2012. DOI: 10.7824/rbh.v11i2.172

GRANELLA, V.; VENTORINI, C. G.; PIGATTO, G. M.; NORNBERG, J. L.; COSTABEBER, I. H. Resíduos de agrotóxicos em leites pasteurizados orgânicos e convencionais. Semina: Ciências Agrárias, Londrina, v. 34, n. 4, p. 1731-1740, jul./ago. 2013. DOI 10.5433/1679-0359.2013v34n4p1731

JIANG, J.; WU, S.; WANG, Y. W.; AN, X.; CAI, L.; ZHAO, X.; WU, C. Carbendazim has to the potential to induce oxidative stress, apoptosis, immunotoxicity and endocrine disruption during zebrafish larvae development. Toxicology In vitro, Rome, v. 29, n. 7, p. 1473-1481, 2015. DOI 10.1016/j.tiv.2015.06.003

JIANG, J.; SHENGGAN, W.; CHANGXING, W.; XUEHUA, A.; CAI, L.; ZHAO, X. Embryonic exposure to carbendazim induces the transcription of genes related to apoptosis, immunotoxicity and endocrine disruption in zebrafish (Danio rerio). Fish \& Shellfish Immunology, Tokyo, v. 41, n. 1, p. 493-500, 2014. DOI: 10.1016/j. fsi.2014.09.037

MARTINI, L. F. D.; CALDAS, S. S.; BOLZAN, C. M.; BUNDT, A. D. C.; PRIMEL, E. G.; AVILA, L. A. Risco de contaminação das águas de superfície e subterrâneas por agrotóxicos recomendados para a cultura do arroz irrigado. Ciência Rural, Santa Maria, v. 42, n. 10, p. 1715-1721, out. 2012.

MONTAGNER, C. C.; VIDAL, C.; ACAYABA, R. D. Contaminantes emergentes em matrizes aquáticas no Brasil: cenário atual easpectos analíticos, ecotoxicológicos e regulatórios. Química Nova, São Paulo, v. 40, n. 9, p. 1094-1110, 2017. DOI: 10.21577/0100-4042.20170091

MONTAGNER, C. C.; VIDAL, C.; ACAYABA, R. D.; JARDIM, W. F.; JARDIM, I. C.; UMBUZEIRO, G. A. Trace analysis of pesticides and an assessment of their occurrence in surface and drinking Waters from the State of São Paulo (Brazil). AnalyticalMethods, v. 6, n. 1, p. 6668-6677, 2014. DOI: 10.1039/C4AY00782D

MORAES, N. V.; GRANDO, M. D.; VALERIO, D. A. R.; OLIVEIRA, D. P. Exposição ambiental a desreguladores endócrinos e alterações na homeostase dos hormônios esteroides e tireoidianos. Revista Brasileira de Toxicologia, São Paulo, v. 21, n. 1, p. 1-8, 2008.

MOREIRA, J. C.; PERES, F.; PIGNATTI, A. C.; DORES, E. C.; VIEIRA, S. N.; STRUSSMANN, C.; MOTT, T. Contaminação de águas superficiais e de chuva por 
agrotóxicos em uma região do Estado do Mato Grosso. Ciência \& Saúde Coletiva, Rio de Janeiro, v. 17, n. 6, p. 1557-1568, 2012.

OLIVEIRA, N. P.; MOI, G. P.; ATANAKA-SANTOS, M.; SILVA, A. M. C.; PIGNATI, W. A. Malformações congênitas em municípios de grande utilização de agrotóxicos em Mato Grosso, Brasil. Ciência \& Saúde Coletiva, v. 19, n. 10, p. 4123-4130, 2014. DOI: 10.1590/1413-812320141910.08512014

PESSOA, M. C. P. Y.; GOMES, M. A. F.; NEVES, M. C.; CERDEIRA, A. L.; SOUZA, M. D. Identificação de áreas de exposição ao risco de contaminação de águas subterrâneas pelos herbicidas atrazina, diuron e tebutiuron. Revista Ecotoxicologia e Meio Ambiente, Curitiba, v. 13, n. 1, p. 111-122, jan./dez. 2003.

RIBEIRO, A. C. A.; DORES, E. F. G. C.; AMORIN, R. S. S.; LOURENCETTI, C. Resíduos de pesticidas em águas superficiais de área de nascente do Rio São LourençoMT: validação de método por extração em fase sólida e cromatografia líquida. Química Nova, São Paulo, v. 36, n. 2, p. 284-290, 2013.

RIBEIRO, M. L.; LOURENCETTI, C.; PEREIRA, S. Y.; MARCHI, M. R. R. Contaminação de águas subterrâneas por agrotóxicos: avaliação preliminar. Química Nova, São Paulo, v. 30, n. 3, p. 688-694, 2007.

RIGOTTO, R. M.; SILVA, A. M. C.; FERREIRA, M. J. M.; ROSA, I. F.; AGUIAR, A. C. P. Tendências de agravos crônicos à saúde associados a agrotóxicos em região de fruticultura no Ceará, Brasil. Revista Brasileira de Epidemiologia, Rio de Janeiro, v. 16, n. 3, p. 763-773, 2013. DOI: $10.1590 / \mathrm{S} 1415-790 X 2013000300019$

RODRIGUES, E. T.; PARDAL, M. A.; LAIZÉ, V.; LEONOR CANCELA, M.; OLIVEIRA, P. J.; SERAFIM, T. L. Cardiomyocyte H9c2 cells presente a valuable alternative to fish lethal testing for azoxystrobin.
Environmental Pollution, v. 206, p. .619-626, 2015. DOI: 10.1016/j.envpol.2015.08.026

SANTOS, T. G.; MARTINEZ, C. B. R. Atrazine promotes biochemical changes and DNA damage in a Neotropical fish species. Chemosphere, v. 89, n. 1, p. 1118-1125, 2012. DOI: 10.1016/j.chemosphere.2012.05.096

SILVA, D. R. O.; AVILA, L. A.; AGOSTINETTO, D.; BUNDT, A. D. C. Ocorrência de agrotóxicos em águas subterrâneas de áreas adjacentes a lavouras em arroz irrigado. Revista Química Nova, São Paulo, v. 34, n. 5, p. 748-752, 2011.

SILVA, R. C.; BARROS, K. A.; PAVÃO, A. C. Carcinogenicidade do Carbendazim e seus metabólitos. Química Nova, São Paulo, v. 37, n. 8, p. 1329-1334, 2014. DOI: 0.5935/0100-4042.20140214

SPADOTTO, C. A.; GOMES, M. A.; LUCHINI, L. C.; ANDRÉA, M. M. Monitoramento do risco ambiental de agrotóxicos: princípios e recomendações. Jaguariúna: EMBRAPA, 2004. 29 p.

TAGERT, M. L.; MASSEY, J. H.; SHAW, D. R. Water quality of mississippi's upper pearl river. Science of the Total Environment, Barcelona, v. 481, n. 1, p. 564-573, 2014.

UNITED STATES ENVIRONMENTAL PROTECTION AGENCY - USEPA. Exclusive use petition extension request for Azoxystrobin. 2006. Disponível em: $<\mathrm{https}$ // www.epa.gov/sites/production/files/2014-04/documents/ azoxystrobin-petition_1.pdf $>$. Acesso em: 21 jun. 2013.

UNITED STATES ENVIRONMENTAL PROTECTION AGENCY - USEPA. Imidacloprid summary document registration review: initial docket. 2006. Disponível em: $<$ https://www.epa.gov/sites/production/files/2014-04/ documents/azoxystrobin-petition_1.pdf $>$. Acesso em: 01 maio 2013. 
